\title{
PERGESERAN OTORITAS HUKUM ISLAM PERSPEKTIF FENOMENOLOGI
}

\author{
Muhaimin \\ Fakultas Syariah, Institut Agama Islam Negeri (IAIN) Jember \\ Jl. Mataram No 1 Kaliwates Jember \\ E-mail: muha75.kamal@gmail.com
}

\begin{abstract}
The Shift of Islamic Law Authority of Phenomenological Perspective. This article seeks to explain the new phenomenon of religious authority in Indonesia, especially in terms of Islamic law and discourse, which seems more authoritative because it is more interactive and direct to the audience (who asks), and is connected through social media; as did Nasaruddin Umar, Musthofa Bisri, Nadhirsyah Hossen, Khalid Basallamah, Abdus Shomad and others. They have different approaches from organizational habits; where Nahdatul Ulama', Muhammadiyah, and other organizations, still use the classical approach in the formulation of Islamic law and the study of the problems of society. Not only that, there is also a difference in the delivery model of an organizational-based authority model in the dissemination of its fatwa. Based on this component also, the author makes the phenomenology of religion (assessment based on the structure of human consciousness) as a study approach and methodical to see the phenomenon. At the same time provide a picture of what should be realized in the context of building Islamic law in accordance with Islamic values and keindonesian. As is known, the personal outlook that 'seems to' break away from institutional influences becomes highly subjective, and based on their own comprehension ability.
\end{abstract}

Keywords: religious phenomenologism; religious authority, media.

Abstrak: Pergeseran Otoritas Hukum Islam Perspektif Fenomenologi. Artikel ini berupaya menjelaskan fenomena baru otoritas keagamaan di Indonesia, khususnya dalam hal hukum dan wacana keislaman, yang seakan-akan lebih otoritatif sebab lebih interaktif dan langsung kepada audience (yang bertanya), serta terkoneksi melalui media sosial; seperti yang dilakukan Nasaruddin Umar, Musthofa Bisri, Nadhirsyah Hossen, Khalid Basallamah, Abdus Shomad dan lain sebagainya. Mereka ini memiliki pendekatan yang berbeda dari kebiasaan organisasional; dimana Nahdatul Ulama, Muhammadiyah, dan organisasi lainnya, masih menggunakan pendekatan klasik dalam perumusan hukum Islam dan kajian terhadap problematika masyarakat. Tidak hanya itu, ada juga perbedaan model penyampaian dari model otoritas berbasis organisasi dalam penyebaran fatwanya. Berdasarkan pada komponen ini pula, maka penulis akan menjadikan fenomenologi agama (pengkajian berdasarkan struktur kesadaran manusia) sebagai sebuah pendekatan studi dan metodik untuk melihat fenomena tersebut. Sekaligus memberikan gambaran apa yang semestinya disadari dalam konteks membangun hukum Islam yang sesuai dengan nilai keislaman dan keindonesian. Sebagaimana diketahui, cara pandang personal yang 'seakan' melepaskan diri dari pengaruh institusional menjadi sangat subjektif, dan berdasar pada kemampuan pemahaman mereka itu sendiri.

Kata kunci: fenomenologi agama; otoritas keagamaan; media.

\section{Pendahuluan}

Era modern yang ditandai salah satunya melalui kemajuan teknologi khususnya dalam bidang informasi (media sosial-ed) mulai diyakini dapat mengubah corak pemikiran, sikap, serta kecenderungan perilaku umat beragama di seluruh dunia, termasuk mereka yang memeluk agama
Islam. ${ }^{1}$ Di lain pihak, ketergantungan masyarakat kontemporer terhadap media, dapat dijadikan alasan kenapa media mampu merubah mindset dan perilaku masyarakat, baik elektronik atau

${ }^{1}$ R., Chados, "Reflectons on the Impact of "The Digital Revoluton" on Art and Religion", Journal of Associaton for Religion and Intellectual life Vol. 62, No. 2, 2012, h. 260-269. 
media alternative (baca; media sosial). Yahoo!TNS, salah satu penyedia search engine selain google, dalam Silvia Fardila, memberikan gambaran bahwa hampir $40 \%$ secara sequence orang Indonesia menggunakan media digital dan internet untuk mengisi hari-hari mereka. Tidak hanya itu yang mengejutkan, pada tulisan yang sama, disebutkan juga bahwa ada peningkatan pengguna media digital dan internet pada setiap tahunnya. ${ }^{2}$

Persoalan yang sering menjadi perbincangan di media sosial dan hampir setiap tahun terjadi dan dianalisa dalam perspektif hukum Islam misalnya, adalah masalah hukum mengucapkan selamat natal bagi umat Kristen di Indonesia. Perbincangan ini kerap kali lamban direspon oleh para ulama ataupun para pemilik otoritas keagamaan di Indonesia. Termasuk juga organisasi-organisasi keagamaan, seperti Majelis Ulama Indonesia, Nahdatul Ulama, dan Muhammadiyah. Akibatnya diskursus ini terus bergulir dan membingungkan sikap keagamaan Umat Islam di Indonesia. Masyarakat Indonesia seakan-akan terkotak pada dua pandangan, yaitu yang memperbolehkan melalui alasan karena menghormati perbedaan keyakinan di balik masyarakat plural di Indonesia, ada pula jawaban bahwa mengucapkan selamat di hari Natal sama seperti mengucapkan selamat ulang tahun kepada Nabi Isa as. Serta pandangan ucapan itu hanya sebatas 'basabasi' kemanusiaan semata. Di pihak yang lain, ada banyak ulama, menggunakan rasionalisasi dan pandangan pribadinya, mengatakan salam terhadap non-muslim berarti sama dengan mereka, sehingga implikasi hukumnya adalah haram. Ada pula pendapat keharaman mengucapkan selamat natal karena tidak pernah dilakukan oleh Nabi Muhammad Saw terhadap agama Nashrani di zamannya, dan alasan-alasan lainnya. ${ }^{3}$

2 Silvia Fadilah "Korelasi Tingkat Adiksi Masyarakat terhadap Internet dalam Pemahaman Keagamaan", Jurnal Al Afkar, Vol. 4, No. 1, 2014, h. 56

3 Perdebatan ini bisa dilihat pada setiap tahun di lini masa media sosial ataupun pada pemberitaan beberapa hari sebelum perayaan natal. Ini adalah salah satu pemberitaan terkait topik tersebut: Lihat liputan detik Pada tahun 2016 terkait MUI Larang Penggunaan Atribut Natal bagi Umat Islam" https://news. detik.com/berita/d-3373614/fatwa-haram-penggunaan-atribut-
Terlepas dari bagaimana relasi, kontribusi, dan dampak media terhadap konstruksi kehidupan masyarakat modern dan kontemporer, tulisan ini diulas untuk melihat fenomena yang lebih spesifik, yakni; bagaimana pemahaman agama, secara fenomenologis, diekspresikan melalui sarana dan prasarana media elektronik atau sosial, bagaimana relasi pengguna media elektronik dan sosial tersebut, dengan seorang ulama yang menggunakan media elektronik dan sosial sebagai sarana dakwah mereka. Dikarenakan disiplin yang penulis geluti berhubungan dengan hukum Islam, maka penulis akan memperbincangkan dalam perspektif hukum Islam khususnya fenomenologisme agama dan kepantasan otoritatif di dalam kerangka berfikir hukum Islam. Terkait fokus yang terakhir ini, penulis menganggapnya lebih penting dibandingkan sebelumnya, sebab akhirakhir ini, ada kecenderungan para ulama, ustadz, kyai, dan akademisi yang punya media sosial atau acara di televisi memberikan pendapat hukum yang berbeda-beda dalam kasus yang sama di masyarakat.

Berdasarkan pada fakta inilah, penulis merasa perlu untuk membahas bagaimana sebenarnya sebuah hukum Islam difatwakan kepada masyarakat umum dalam bingkai otoritas organisasi keagamaan, otoritas individual ulama, dan bagaimana pula pola dan prosedur yang idealnya dilakukan oleh seorang mufti, fakih dan ulama dalam menghasilkan sebuah pandangan produk hukum. Setelah itu, penulis juga akan berupaya membuat kategori dialogisinterpretatif antara pertanyaan kepada mereka (baca; pemegang otoritas keagamaan) yang disampaikan oleh masyarakat umum melalui media masa. Pertanyaan yang diajukan dan jawaban hukum itu, akan penulis lihat dari linimasa media elektronik ataupun sosial, terkait beberapa kasus yang terjadi di era kontemporer ini, misalnya; hukum mendirikan negara Islam dan melaksanakan syariat Islam di Indonesia, hukum memilih non-muslim sebagai pemimpin, serta persoalan-persoalan muamalah lainnya yang berkembang selama proses penulisan.

nonmuslim-mui-itu-hanya-untuk-umat-islam, (diakses pada 10 Januari 2017) 
Untuk merangkai tulisan ini secara sistematis, penulis akan membuat sistematika kajian ini sebagaimana berikut: Pertama, otoritas keagamaan ragam pergeseran pemegang otoritas keagamaan. Kedua, fenomenologisme agama dan konstruk kesadaran otoritatif. Ketiga, catatan akhir etika kepedulian pemegang otoritas keberagamaan.

\section{Otoritas Keagamaan Islam di Indonesia}

Kata otoritas, dalam beragam disiplin ilmu, sering dimaknai sebagai hak untuk mengeksekusi kekuasaan. Oleh karenanya, terkadang seseorang memaknai otoritas itu pada dimensi yang fungsionalisme. Pasalnya, mereka melihat bahwa otoritas harus dimainkan pada konteks dan kontestasi spesifik, bukan seluas-luasnya layaknya sebuah kekuasaan. Dalam bahasa yang lebih sederhana, otoritas mengandung kerangka kerja, teologi, dan pertanggung jawaban akademik, atas pekerjaan yang dilakukan. Meskipun, pada kenyataanya, orang-orang yang diberikan otoritas ini, acapkali mendefinisikan apa peran, tugas, dan tanggung jawabnya sendiri melebih dari apa yang sudah dicatatkan dan disematkan oleh pemilik kuasa absolut. Semisal, dalam konteks negara demokrasi kekuasaan absolut terletak pada kedaulatan rakyat yang memberikan mandat kepada para pemimpin yang sudah dipilihnya.

Penulis berbeda dengan Rumadi dalam konteks agama, yang menyebutkan bahwa posisi tuhan, teks Alquran, dan Nabi Muhammad sebagai pemilik otoritas absolut. ${ }^{4}$ Bagi penulis, tiga sumber ajaran Islam ini adalah penentu otoritas mereka yang hidup setelah era kenabian. Alquran dan Nabi Muhammad merupakan pemberi lakob kerja para sekumpulan ulama, model berfikir individu berbasis nilainilai keagamaan dan prosedur etik bagaimana memahami agama, khususnya agama Islam. Pada bagian ini karena levelnya adalah otoritas, idealnya, tidak ada sebuah kepastian hukum terkecuali produk-produk pemikiran yang dievaluasi melalui kontestasi dan dilegitimasi

4 Rumadi, "Islam dan Otoritas Keagamaan...", Jurnal Walisongo, Vol. 20, No. 1, 2012, h. 33 oleh common sense manusia secara umum. Tapi memang, penulis juga mengakui bahwa, meski seorang ulama atau sekumpulan ulama memiliki otoritas untuk menterjemahkan peran yang disematkan, terkadang umat Islam menafikan sumber pandangan kuasa itu, akibat ketidak mampuan untuk menterjemahkan kebenaran itu sendiri. Oleh sebab kurangnya pemahaman dan tidak adanya kompetensi untuk memahami kandungan makna yang ada di dalam Alquran dan sumber lainnya. Posisi para pemimpin (amir), pemikir Islam (ulama), dan intelegensia muslim bermain dalam kontestasi tersebut.

Terlepas dari itu, penulis cukup menyukai bagaimana postur kegelisahan akademik yang dipaparkan Rumadi dalam hal memaknai apa dan siapa sebenarnya yang memiliki otoritas keagamaan, khususunya di Indonesia yang memilih sistem demokrasi dibandingkan teokrasi. Pada level pertama, ia mempertanyakan siapa sebenarnya yang berhak untuk memiliki otoritas resmi dari sumber kuasa ajaran Islam. Pada konteks ini, ia menggunakan pendekatan historis untuk menilai bagaimana perdebatan kelompok kuasa yang dipilih umat Islam dan kelompok lain yang keluar dari pandangan tersebut, karena menganggap pemimpinnya sudah melampaui otoritas yang dimiliki. Singkatnya, baginya tidak ada yang berhak untuk menjadi satu-satu wakil Tuhan, Alquran, dan Nabi Muhammad pasca era kenabian. Yang ada hanyalah sebuah potret perdebatan dan kontestasi pemahaman keagamaan yang diproduksi berdasarkan dialektika dan pemahaman dari sumber-sumber tersebut. Pandangan ini dilandaskan pada pemahaman Kholeed Abou al Fadl tentang istilah pemangku otoritas dan pemegang otoritas, yang bisa dimaknai sebagai pembedaan kontestasi di eraera masa lampau tersebut. ${ }^{5}$

Pada level kedua, kegelisahan akademik yang dibuat Rumadi ialah belajar dari sejarah yang sudah ada sebelumnya, bagaimana kemudian membedakan otoritas agama dan politik. Hal ini penting sebab, otoritas agama yang bercampur dengan otoritas politik akan mengakibat adanya standar ganda terhadap

\footnotetext{
${ }^{5}$ Rumadi, Rumadi, “Islam dan Otoritas...”, h. 34-37
} 
pemaknaan otoritas; seseorang yang melawan otoritas politik, berarti melawan pula otoritas agama, demikian halnya sebaliknya, tergantung pada pertimbangan kepentingan yang akan digunakan oleh para penguasa untuk mensustain politiknya. Di pihak yang lain, ia juga menyandarkan otoritas mutlak (keagamaan) ke politik (yang relatif pada ukuran persepsi manusia) akan menjadikan agama yang memiliki nilai kesucian, tercemari oleh interpretasi subjektif para politisi yang bisa saja tidak mempertimbangkan agama sebagai pilihan kebijakan politik mereka. Dia mencontohkan bagaimana perselingkuhan agama dan politik dalam kurun kesejarahan yang ada di Indonesia; dari masa pembentukan hingga hari ini. ${ }^{6}$

Pada level ketiga, kegelisahan dia yang menarik adalah apakah Majelis Ulama (selanjutnya disingkat MUI) Indonesia adalah pemegang otoritas agama Islam di Indonesia? Baginya, sebagai umat Islam yang banyak menganut aliran Sunni, umat Islam Indonesia tidak terpaku hanya pada MUI. Di Indonesia ada Nahdatul Ulama, Muhammadiyah, dan tokoh Islam lokal yang membangun interkoneksitas dengan masyarakat secara langsung, sehingga menjadi rujukan umat untuk menyelesaikan problemproblem keagamaan yang dihadapi.7 Namun, pandangan Rumadi ini, bisa saja dianggap salah, sebab, secara politis dan sosiologis, umat Islam Indonesia dan pemerintah Indonesia 'mengakui' bahwa produk kajian hukum yang dilakukan oleh MUI memiliki legitimasi lebih kuat dibandingkan organisasi masyarakat atau tokoh pemikir Islam lainnya. Ditambah lagi, fatwa-fatwa MUI yang sebenarnya dibuat untuk menjawab pertanyaan masyarakat ter-establish ke ruang publik melalui media elektronik atau massa. Berbeda dengan pandangan para tokoh atau organisasi keagamaan yang hanya dibaca dan disebarkan kepada para pengikutnya saja.

Selain Rumadi, terdapat Azyumardi Azra, Kees Van Dijk, dan Nico J.G Kaptein ${ }^{8}$ yang sempat

\footnotetext{
${ }^{6}$ Rumadi, "Islam dan Otoritas...", h. 38

7 Rumadi, "Islam dan Otoritas...", h. 40

8 Azyumardi Azra, Kees Van Dijk, dan Nico J.G Kaptein, Varieties of religious Authority; Changes and Challenges in $20^{\text {th }}$ Century Indonesian Islam, (Singapore, ISAS Publishing, 2010), h. x
}

mengadakan acara atau seminar international untuk mengetahui pemaknaan otoritas agama Islam yang bervariasi dari pelbagai perspektif; apakah itu dalam tingkat lokal, nasional, internasional, atau interelasi antara kelompok masyarakat dengan organisasi kemasyarakatan yang ada di negara-negara masing-masing. Haula Noor, kemudian membuat konklusi terhadap beberapa topik yang ada di dalam buku itu menjadi empat hal penting; pertama, relasi ulama dan proses pembentukan fatwa; apakah itu individual ataupun institusional. Fatwa individual ini kemudian termaktub dan tercatat pada kitab atau karya tulis seorang ulama tersebut; Marc Gaborieau adalah penulis yang mengaitkan beberapa kitab-kitab otoritaif sebagai sumber hukum Islam di India pada serial tulisan di dalam buku Azra ini. Kedua, relasi thariqat dan pandangan yang dibuat oleh para mursyid sebagai pemilik otoritas keagamaan pada budaya sufisme. Ketiga, dakwah di masyarakat urban. Keempat, masalah pendidikan dan reproduksi otoritas melalui proses konstruksionisme yang ada di lingkungan sekolah atau madrasah tersebut. ${ }^{9}$

Pada kesimpulannya, apapun pembacaan orang terkait otoritas keagamaan, tampaknya memang tidak bisa dibuat sebuah formula baku, siapa sebenarnya yang lebih berhak dan memiliki nilai kepantasan untuk menentukan kebenaran produk hukum yang dihasilkan. Semua 'pemegang otoritas' tampaknya bisa memainkan peranannya masing-masing pada komunitas atau individunya masing-masing. Maka tidak salah apabila, Kremer dan Schmidt ke mengatakan bahwa otoritas agama merupakan "the ability (chance, power, or right) to define correct belief and practice, or orthodoxy and orthopraxy, respectively; to shape and influence the views and conduct of others accordingly; to identify, marginalize, punish or exclude deviance, heresy and apostasy and their agents and advocates". ${ }^{10}$

Adapun yang berkaitan dengan bagaimana

\footnotetext{
9 Haula Noor, "Dinamikan Otoritas Keagamaan di Indonesia", Jurnal Indo-Islamika Vol. 1, No. 2, 2012. h. 331-337

10 Kramer \& S. Schidtke (eds), Speaking for Islam: Religious authorities in Muslim societies, (Leiden: Brill Academic Publishers, 2006), h. 1
} 
pola dan desiminasi otoritas keagamaan memberikan pengaruhnya kepada pemeluk agama tertentu. Cara baca yang paling sederhana adalah melalui kerangka berfikir spasial. Artinya, pandangan seorang pemegang otoritas keagamaan bisa diketahui melalui dialog antara penanya dan pemegang otoritas tersebut di ruang tertutup pada aktivitas dialog itu. Tapi, cara pandang seperti ini, pasti banyak yang menyangkalnya. Pasalnya, di era modern dan global, sudah tidak ada ruang tertutup lagi yang dapat mengisolasi kegelisahan seseorang dan jawaban dari pemegang otoritas keagamaan. Bahkan, perkembangan teknologi dan tipetipe komunikasi sudah sangat mempengaruhi bagaimana pandangan ulama atau cendikiawan terkait persoalan-persoalan agama Islam yang ada; baik itu di Indonesia ataupun di dunia luar. Anggapan bahwa Islam sudah tidak sekedar persoalan lokal bisa dilihat dari beberapa karya penelitian orientalis, seperti Peter Mandaville, Oliver Roy, dan beberapa peneliti lainnya.

Terkait dengan transmisi dan sosialisasi para pemegang otoritas keagamaan tersebut, Jajat Burhanudin memberikan gambaran apa yang terjadi di Indonesia melalui pandangan historis. Dia memaparkan bagaimana media cetak kelompok-kelompok keberagamaan umat Islam yang ada di era Hindia Belanda hingga pada abad ke 20, memberikan peran untuk menumbuhkan pemahaman sikap-sikap keberagamaan Islam di Indonesia. Ada banyak buku, koran, dan media lain yang disebarkan oleh para ulama modernis ataupu tradisionalis untuk menjawab persoalan yang berkembang di dalam masyarakat Indonesia. " Beberapa tahun selanjutnya, Jajat Burhanudin memperbaharui kajiannya, terkait peran otoritas kelompok modern dan tradisional pada pengembangan umat Islam di Indonesia ${ }^{12}$ ia menafikan bahwa pandangan seorang ulama (pemegang otoritas)

11 Jajat Burhanuddin, "The Fragmentation of Religious Authority; Islamic Printed Media in Early $20^{\text {th }}$ Century Indonesia", Jurnal Studia-Islamika, Vol. 11, No. 1, 2004, h. 47

${ }^{12}$ Jajat Burhanuddin "Traditional Islam and Modernity; Some note Changing of the Ulama' in Early $20^{\text {th }}$ Century Indonesia" dalam Azyumardi Azra, Kees Van Dijk, dan Nico J.G Kaptein, Varieties of religious Authority; Changes and Challenges in $20^{\text {th }}$ Century Indonesian Islam, (Singapore: ISAS Publishing, 2010), h. 69-70 sudah tidak bisa lagi dispesialisasikan dalam wujud yang mikro; seperti antara otoritas ulama di pedesaan dan perkotaan. Sebab, teknologi dan produk media hari sudah melewati ambang batas teritorial. Tidak jauh berbeda dengan J. Burhanuddin, Mutohharun Jinan mengkaji media baru dan pergeseran otoritas keagamaan di Indonesia. Media baru yang dimaksud adalah internet dan segala aspek yang disediakan untuk mengkoneksikan seseorang dengan orang lainnya. Menurutnya, berdasarkan pada pengkajian panjang tentang topik tersebut, disimpulkan bahwa ada impersonalisasi dan desentralisasi otoritas keagamaan (Islam) di Indonesia. ${ }^{13}$

Hampir sama dengan yang diungkapkan oleh Mutohharun Jinan, Anita L. Cloete membuat terma baru dengan menyebut 'mediated religion' untuk melihat tampilan agama-agama yang dikontestasikan pada media online dan sarana tekhonologi lainnya. Kesamaan itu terlihat pada kesimpulan pembacaan dia terhadap media dan otoritas keagamaan di era postmodern ini. ${ }^{14}$ Hal yang bisa menjadi catatan penting dalam catatan Cloete ini adalah bahwa pergeseran otoritas keagamaan tidak sekedar berubah dari sisi institusional, Ulama dan buku otoritatif, melainkan beralih pada sudut pandang media yang dibingkaikan, skenario yang dibuat untuk membuat tampilan tertentu pada sebuah media elektronik, serta audience media itu sendri. Artinya, intensitas dan kebergantungan pemeluk agama terhadap media baru ini dapat merubah sudut pandang dia terhadap siapapun yang sudah dianggap menjadi pemegang otoritas keagamaan sebelumnya. Selain itu, dampak dari interaksi dan interkonektifitas seseorang melalui media tersebut akan membentuk relasi antara individu yang satu dengan lainnya. Dalam bahasa lain, otoritas keagaman sudah menjadi keterikatan individu pemeluk agama

13 Mutohharun Jinan, “New Media dan Pergeseran Otoritas Keagamaan Islam di Indonesia", Jurnal Lektur Keagamaan, Vol. 10, No. 1, 2012, h. 181-208. Lihat tulisan serupa, Mutohharun Jinan "Intervensi New Media dan Impersonalisasi Otoritas Keagamaan di Indonesia", Jurnal Komunikasi Islam Vol. 03, No. 02, 2013, h. 334-335

${ }^{14}$ Anita L. Cloete, "Mediated religion: Implicatons for religious authority” AOSIS. Tahun 2016, h. 5 
bersama satu tokoh agama yang bisa diajaknya untuk mendiskusikan persoalan-persoalan keberagamaan yang dihadapinya. Setidaknya, inilah dinamika yang terangkum terkait, apa, siapa, dan bagaimana otoritas keagamaan itu dimunculkan dan diperdebatkan di ruang publik. Pada pembahasan selanjutnya, penulis akan menggambarkan fenomena baru yang unik, terkait pertanyaan serupa; apa, siapa, dan bagaimana otoritas keagamaan diekspresikan di 'Jaman Now'.

Berdasarkan pada gambaran terakhir di atas, seakan sangat tegas bahwa ada pergeseran terkait apa, siapa, dan bagaimana otoritas keagamaan (Islam) di Indonesia. Namun tampaknya, pemaknaan terhadap otoritas keagamaan sudah harus mulai diredefinisi terlebih diakibarkan munculnya aktor intelektual baru yang ada di Indonesia, kontestasi politik dan ideologis yang mewarnai corak keislaman di Indonesia, serta terkait bagaimana relasi otoritas keagamaan; apakah itu institusional, aksidental (karena kebutuhan terhadap jawaban pada persoalan agama), atau ketidak pantasan seseorang merepresentasikan dirinya sebagai Ulama atau tokoh agama. Untuk lebih jelasnya, penulis akan memberikan pemaparan apa saja fenomenafenomena kekinian dan bagaimana tanggapan para akademisi terkait dengan otoritas keagamaan Islam di Indonesia hari ini.

Pertama, Najib Burhani adalah salah seorang cendikiawan muslim yang meresahkan fenomena Aksi Bela Islam berepisode di Pilkada Jakarta Tahun 2017 yang lalu. Menurutnya, jika diruntut bagaimana proses dramatisasi aksi dan demonstrasi tersebut, seakan-akan membentuk fragmentasi baru otoritas keagamaan di Indonesia. Buya Syafi'i Ma'arif, Said Aqil Siradj, dan Haedar Nashir, termasuk di panggung politik, seperti Joko Widodo, tidak mampu membendung dan menyerukan agar para pendemo tersebut mengurungkan niatnya. Di akhir tulisannya, dia mempertanyakan apakah kemudian akan nada perubahan otoritas keagamaan, dari yang sudah otoritaif seperti Nahdatul Ulama dan Muhammadiyah?'15 Kedua, fenomena ke-

15 Lihat Opini Koran Sindo: Najib Burhani Aksi Bela Islam dan Fragmentasi Otoritas keagamaan: https://nasional. salahan penjelasan ajaran keagamaan dan tulis Arab di sebuah televisi swasta di Indonesia. Fenomena ini memantik Siti Nurul Hidayah untuk mempertanyakan dua hal penting; representasi ulama (pemegang otoritas keagamaan) yang dihadirkan di televisi dan alasan televisi yang cenderung memikirkan aspek-aspek komersialisme dibandingkan subtansi dari dakwah Islam yang ideal bagi umat Islam. ${ }^{16}$

Ketiga, kembalinya perdebatan terkait siapa sebenarnya yang memiliki hak terhadap otoritas keberagamaan yang ada di Indonesia. ${ }^{17}$ Keempat, meski penulis agak sulit menemukan rujukan pandangan fenomenalnya, ada perdebatan yang selalu ramai dan lama di media sosial, apabila persoalan agama menjadi topik perbincangan mereka. Seakan-akan, jika diamati secara seksama, ada ruang deligitimasi oleh pemuka agama yang satu dengan pemuka agama lainnya. Pada bagian keempat ini, bisa saja, diasumsikan bahwa otoritas keagaman Islam pasca kontestasi politik dan aksi bela Islam menghadirkan perubahan audience baik itu pengguna media sosial; ataupun yang hanya melihat pemberitaan di media masa atau televisi. Misalnya, sama seperti apa yang disebutkan oleh Najib Burhani di atas, para netizen cenderung lebih suka mendengarkan dan mengikuti pandangan kelompok-kelompok conservative radikal dibandingkan kelompok moderat. Atau dalam bahasa-bahasa 'me-me' yang ada di netizen mereka lebih suka yang Islam-nya Kaffah dibandingkan yang setengahsetengah. Atau pula, ada fenomena menarik kala di media sosial ada gambar yang membandingkan keilmuan seorang kyai/ulama dan ustaz dengan salah seorang Muallaf yang menjadi pendakwah Islam, dan seterusnya.

sindonews.com/read/1168539/18/aksi-bela-islam-danfragmentasi-otoritas-keagamaan-1483668174, (diakses pada tanggal 10 Januari 2018)

${ }^{16}$ Lihat Opini Siti Nurul Hidayah "Tele Dai dan Persoalan Otoritas Keagamaan” https://news.detik.com/kolom/d-3770783/ tele-dai-dan-persoalan-otoritas-keagamaan, (diakses pada tanggal 10 Januari 2018)

${ }^{17}$ Lihat Artikel terkait Media dan Otoritas Pemikiran Islam pada https://www.hidayatullah.com/artikel/ghazwulfikr/read/2017/02/16/111930/sihir-media-dan-kampanye-antiotoritas-agama.html, (diakses pada tanggal 10 Januari 2018) 
Betapapun itu, faktanya hari ini penggunaan istilah pemegang otoritas keagamaan memang sudah sulit definisikan, lebih-lebih apabila berhubungan dengan pengaruhnya terhadap perubahan sikap umat Islam secara luas. Para aktor dan ulama acapkali berdebat dalam persoalan keagamaan, dan tidak selalu menghasilkan jawaban yang satu kata. Termasuk misalnya, fatwa-fatwa yang dikeluarkan oleh MUI. Para akademisi dan kelompok moderat Islam, seringkali, mempertanyakan fatwafatwa MUI yang controversial akhir-akhir ini, dengan model yang lebih tegas dibandingkan sebelumnya. Di pihak yang lain, ada juga dan sering dilihat di media sosial atau televisi, para pemegang otoritas keagamaan berbeda sikap dan berdebat secara terbuka. Maka dari itu, di era hari sekarang, akan sangat sulit bagi umat Islam untuk mendapatkan jawaban sama. Semua masih terbuka untuk dikritik, baik oleh orang awam atau bahkan ulama lainnya. Oleh sebab itulah, penulis ingin menawarkan sebuah paradigma baru bagaimana semestinya cara berfikir keberagamaan ditampilkan berasaskan pada kesadaran penuh tanggung jawab, menggunakan paradigma fenomenologisme agama dalam melihat perdebatan otoritas keagamaan hari ini.

\section{Fenomenologisme Beragama dan Konstruk Kesadaran Islam Otoritatif}

Sebelum memasuki kerangka baca fenomena pergeseran otoritas di atas, serta bagaimana semestinya membangun kesadaran fenomenologisme keberagamaan. Ada baiknya penulis paparkan terlebih dahulu posisi fenomenologi dalam studi agama. Sebagaimana mafhum, fenomenologi merupakan aliran kefilsafatan yang membicarakan tentang kesadaran seseorang akan esensi dan eksistensi manusia. Fenomenologi membicarakan intensionalitas (kesengajaan) seseorang dalam bersikap. Fenomenologi membicarakan reduksi psikologis pada fenomena-fenomena yang ada di hadapan seseorang. Sedangkan sebagai sebuah kerangka baca fenomena. Douglas Allen, dalam Hinnels ${ }^{18}$

${ }_{18}$ Douglas Allen, "Phenomenology of Religion" dalam J. R Hinnels, Rutledge Companion of Religious Study, (New York: Routledge, 2005), h. 78 menyatakan bahwa fenomenologi agama memulai berfikir bahwa agama hadir berdasarkan pada pengalaman keberagamaan seseorang. Setiap orang bisa mengekspresikan dirinya sebagai bagian dari agama atau menganggap fenomena tersebut sebagai agama; apakah pada bentuk dan wujud tradisional, institusional, atau relasional. Maka dari itu, seseorang yang tidak mau memahami akan kebiasaan dan dimensi space yang ada di dalam agama, dimungkinkan seseorang itu tidak memiliki pengalaman keberagamaan. Dhavamony Mariasusai mengatakan bahwa Fenomenologi agama pertama kali diperkenalkan Pierre Daniel Chantepie de la Saussaye (1848-1920) dalam bukunya berjudul "Lehrbuch der Religionsgeschichte". Dalam buku yang diterbitkan pada tahun 1887 tersebut, ia meneliti fenomen-fenomen historis yang terdapat dalam suatu agama seperti ritus (upacara), mitos dan praktik keagamaan. Lewat asas kerja demikian, ia akan memperoleh gambaran secara komprehensif mengenai suatu agama terutama sejarah kemunculan dan perkembangannya. Asas kerja yang digunakan kemudian disebut sebagai fenomenologi historis agama yang bermakna "penyelidikan sistematis dari sejarah agama, yang bertugas mengklasifikasikan dan mengelompokkan menurut cara tertentu sejumlah data yang tersebar luas sehingga suatu pandangan yang menyeluruh dapat diperoleh dari isi agama-agama tersebut dan makna religius yang dikandungnya". ${ }^{19}$

Setelah karya monumental De la Saussaye di atas, pada tahun 1933 muncul sebuah buku yang secara eksplisit berbicara tentang fenomenologi agama yang ditulis oleh Gerardus Van der Leeuw (1890-1959). Bukunya diberi judul Phänomenologie der Religion, “Fenomenologi Agama”. Argumentasi kunci yang ingin ditelitinya adalah pengalaman religius sebagai perjumpaan antara subjek dan objek. Dalam studinya itu, ia menandaskan bahwa ada kaitan erat antara objek dan subjek terutama ketika subjek bersentuhan langsung dengan obyek yang diteliti. Karena itu, dalam bagian pertama bukunya tersebut, ia menguraikan tema objek agama, sedangkan dalam bagian

${ }^{19}$ Mariasusai Dhavamony, Fenomenologi Agama, terj. Tim Kanisius, (Yogyakarta: Kanisius, 1999), h. 8. 
kedua mengelaborasi tema subjek agama. ${ }^{20}$ Dengan membicarakan keduanya secara khusus dalam bagian-bagiannya, Van der Leuw ingin memperoleh pemahaman utuh tentang objek dan subjek agama. Karena itu, dalam bagian ketiga dari magnum opus-nya itu, ia membahas tema relasi antara objek dan subjek agama. Dalam bagian keempat dan kelima secara berurut-turut ia membahas tema dunia agama, dan bentuk agama.

Uraian selanjutnya, Van der Leeuw memaparkan definisi fenomenologi agama, ia memakai via negativa atau jalan negasi dalam merumuskan apa itu fenomenologi agama. Menurutnya, fenomenologi agama bukan merupakan puisi agama, bukan sejarah agama, bukan psikologi agama, bukan filsafat agama dan bukan juga teologi agama. ${ }^{21}$ Lewat via negativa di atas, maka munculah via positiva, yaitu rumusan afirmatif mengenai fenomenologi agama yaitu sebagai ilmu yang secara khusus mengamati fenomena-fenomena yang tampak dalam suatu agama sebagaimana adanya sebelum direfleksikan. Dengan demikian akan ditemukan hakekat dari fenomena-fenomena yang tampak. Namun hakekat dari fenomena-fenomena itu menurut Van der Leeuw tetap merupakan suatu misteri, karena ia tidak menampakan diri atau tersembunyi (nascosto). ${ }^{22}$

Oleh karena itu, ia mengelaborasi lima tahap dalam mempelajari fenomenologi agama. ${ }^{23}$ Tahap pertama adalah penamaan fenomen-fenomen yang hadir seperti; persembahan, pengudusan, doa, penyelamat, mitos, dan sebagainya. Dalam tahap ini, kita mengelompokan nama-nama yang dikenakan pada fenomen-feomen yang sama. Tahap kedua adalah fenomen-fenomen yang telah diberi nama lantas dijadikan sebagai pengalaman sendiri. Dengan kata lain, fenomenafenomena tersebut harus menjadi pengalaman yang nampak dalam dunia kehidupan, yang kurang lebih sama bagi setiap manusia. Tahap ketiga adalah mencari arti dari setiap fenomen

${ }^{20}$ Geradus Van der Leeuw, Fenomenologia Della Religion, (Torino: Bollati Boringhieri, 1992), h. 5-265.

${ }^{21}$ Geradus Van der Leeuw, Fenomenologia della... h, 540-542.

${ }^{22}$ Geradus Van der Leeuw, Fenomenologia della... h, 538.

${ }^{23}$ Geradus Van der Leeuw, Fenomenologia della....h, 543 yang tampak. Tahap keempat adalah menentukan tipe-tipe dari fenomen-fenomen yang tampak. Penentuan tipe dilakukan berdasarkan ciri-ciri yang kurang lebih sama. Akhirnya tahap kelima adalah menjelaskan makna dari fenomenafenomena yang tampak sehingga bermakna bagi subjek.

Dalam artikel berjudul "Phenomenology and Study of religion: the archeology of an Approach", George A. James menampilkan dua pandangan kontras mengenai fenomenologi agama yaitu pandangan C. J Bleeker dan pandangan Raffaelle Pettazzoni.. ${ }^{24}$ Menurut C. J Bleeker, fenomenologi agama adalah studi pendekatan agama dengan cara membandingkan berbagai macam fenomena dari bidang yang sama antara berbagai macam agama. Fenomen-fenomen yang diteliti adalah tata cara peribadatan, doa-doa, upacara inisiasi, perwujudan iman dalam kehidupan sehari-hari, dan sebagainya. Melalui hal ini Bleeker lantas berusaha menemukan hakekat yang sama dari fenomen-fenomen yang berbeda. Dalam penelitiaannya, ia merasa sangat berhutang budi kepada Husserl yang telah memperkenalkan metode fenomenologi, terutama gagasannya tentang epoche dan pandangan eidetis, akan tetapi gagasan Bleeker ini, dikritisi secara tajam oleh Pettazzoni. ${ }^{25}$ Menurutnya fenomenologi agama tidak harus memuat perbandingan tipologis antara berbagai macam fenomena agama, melainkan pendekatan terhadap problem-problem yang muncul dalam pengamatan data agama berdasarkan suatu hegemoni yang mengatasi disiplin ilmu-ilmu lainnya seperti filologi agama, arkeologi agama, etnologi agama, sosiologi agama, psikologi agama dan sebagainya. Ilmu agama, demikian kata Pettazzoni, mengoordinasi data agama, menetapkan hubungan-hubungan, dan mengelompokkan fakta agama menurut hubungan-hubungan tersebut. Dalam konteks ini fenomenologi agama hanyalah salah satu bagian ilmu agama di samping sejarah agama, psikologi

${ }^{24}$ SJ Sudiarja A, Pengantar, dalam Mariasusai Dhavamony, Fenomenologi Agama, (Yogyakarta: Kanisius, 1999), h. 7

${ }^{25}$ Raffaele Pettazzoni lahir pada tahun 1883 di Bologna, Italia. Beliau secara khusus meneliti fenomenologi historis agama dan memberi kontribusi yang sangat penting dalam mengembangkan studi agama-agama. Pettazzoni merupakan guru besar sejarah agama pada Universitas Roma (1924-1953). 
agama, antropologi agama dan sebagainya. Oleh karena itu benar afirmasi Dhavamony yang menegaskan bahwa fenomenologi agama adalah ilmu empiris, ilmu manusia yang menggunakan hasil-hasil ilmu manusia lainnya seperti psikologi agama, sosiologi, dan antropologi agama. ${ }^{26}$

Di tengah keragaman pemahaman terhadap fenomenologi agama, perlu dicermati definisi yang cukup komprehenshif yang diberikan oleh James L. Cox. Dengan menggunakan konsepkonsep Husserl, Cox mendefinisikan fenomenologi agama dengan pengertian sebagai berikut: "A method adopting the procedures of epoche (suspension of previous judgements) and eidetic intuition (seeing in to the meaning of religion) to the study of the varied of symbolic expressions of that which people appropriately respond to as being unrestricted value from them." ${ }^{27}$ Dari pengertian ini, ada dua unsur pokok yang melekat dalam pendekatan fenomenologi, yaitu epoche, yang berarti "pengurungan semua anggapan dan penilaian sebelumnya", dan eidetic intuition yang mengandung arti "melihat ke dalam jantung makna agama”. Dengan kedua cara ini, fenomena agama dan pengalaman keberagamaannya dapat diketahui struktur-struktur mendasarnya. Berdasarkan pada pendefinisian di atas pula, para fenomenolog kemudian memberikan beberapa langkah operasional dalam membacan dan mengembangkan kajian-kajian fenomenologi agama. Adapun langkah operasional tersebut adalah: ${ }^{28}$ 1) Mengklasifikasikan fenomena keagamaam dalam kategorinya masing-masing seperti kurban, sakramen, tempat-tempat suci, waktu suci, kata-kata atau tulisan suci, festival dan mitos. Hal ini dilakukan untuk dapat memahami nilai dari masing-masing fenomena. 2) Melakukan interpolasi dalam kehidupan pribadi peneliti, dalam arti seorang peneliti dituntut untuk ikut membaur dan berpartisipasi dalam sebuah keberagamaan yang diteliti untuk memperoleh pengalaman dan

${ }^{26}$ Mariasusai Dhavamony, Fenomenologi Agama....., h. 43

27 James L. Cox, Exspressing the Sacred: An Introduction to the Phenomenology of Religion, (Harare: University of Zimbabwe, 1992), h. 24.

${ }^{28}$ Dikutip dari Rev. Emeka C. Ekeke \& Chike Ekeopara, "Phenomenological Approach to The Study of Religion A Historical Perspective," European Journal of Scientific Research, Vol. 44, No. 2, 2010, h. 271. pemahaman dalam dirinya sendiri. 3) Melakukan "epoche" atau menunda penilaian (meminjam istilah Husserl) dengan cara pandang yang netral. 4) Mencari hubungan struktural dari informasi yang dikumpulkan untuk memperoleh pemahaman yang holistik tentang berbagai aspek terdalam suatu agama. 4) Tahapan-tahapan tersebut menurut Van der Leeuw secara alami akan menghasilkan pemahaman yang asli berdasarkan "realitas" atau manifestasi dari sebuah wahyu. 5) Fenomenologi tidak berdiri sendiri (operate in isolation) akan tetapi berhubungan dengan pendekatan-pendekatan yang lain untuk tetap menjaga objektivitas.

Lantas bagaimana posisi umat Islam hari ini melihat kontestasi, pergeseran, perebutan, dan pendelegitimasian otoritas Ulama atau institusi keberagamaan tradisonal yang sudah ada sebelum Indonesia hadir sebagai sebuah negara?. Menurut penulis fenomena ini bisa berada pada ruang diskursif semata, namun di pihak yang lain bisa mempengaruhi dan mengkhawatirkan banyak orang apabila tidak sesegera mungkin di respon dengan baik. Maka dari itu, penulis akan berupaya membaca ulang beberapa fenomena yang sudah disebutkan dia atas, kemudian berupaya menempatkan posisi fenomenologisme agama sebagai sikap sesuai yang sudah penulis paparkan sebelumnya. Pertama, fenomena kontestasi dan perebutan otoritas keagama pasca aksi bela Islam (sebagaimana disebutkan Najib Burhani). Bagi penulis, kemenangan ini tidak bisa dilepaskan dari cara berfikir laten umat Islam, yang kemudian terbaca oleh kelompok radikal yang ada di Indonesia, yakni; MUI sebagai sumber hukum atau fatwa keagamaan yang paling memiliki legitimasi religious dan sosial. MUI, dalam semua kadar kekurangan dan kontroversi produk fatwanya, dianggap masyarakat sebagai polisi aqidah dan hukum Islam. Kristalisasi demikian dilakukan secara konsisten oleh MUI. Bahkan tidak jarang, MUI mengeluarkan sikap dan fatwa keagamaan pada ruang hukum muamalah (tata pergaulan sosial) yang secara fighiyah tidak bisa dihakimi oleh institusi. Misalnya, persoalan-persoalan hukum pertemanan dan bersosialisasi dengan non-muslim. 
Penulis bersepakat dengan Masdar Hilmy yang mengatakan bahwa, kegagalan dan kekalahan perang otoritas keagamaan NU dan Muhammadiyah dalam menyampaikan moderatisme akibat dari kekalahan memainkan peran otoritatif di ruang publik. Legitimasi MUI, yang berbeda dengan NU dan Muhammadiyah menjadikan kelompok radikal berlindung dibalik kuasa MUI. Di tahun 2013 lalu Masdar Hilmy merekam bagaimana politik deradikalisasi kelompok radikal, kemudian ditanggapi menggunakan politik balas dendam oleh kelompok radikal (backlash of radical Islamist to deradicalization project in Indonesia). Dalam pandangan Masdar Hilmy, ada dua bentuk gerakan balas dendam yang dipakai oleh kelompok radikal dalam projek deradikalisasi. Pertama melakukan kontestasi wacana melalui penerbitan buku, tulisan di media masa, hingga penjelasan-penjelasan apologetic yang ditampilkan di dalam werbsite mereka sendiri. Kedua, perlawanan berbasis pada gerakan, apakah itu demonstrasi atau melalui gerakan anarkistis dalam tingkat lokal. ${ }^{29}$

Hal menarik dari wacana yang dihantarkan Masdar Hilmy, dalam pembacaan penulis, ialah strategi yang digunakan untuk melakukan perlawanan terhadap program yang dilaksanakan oleh pemerintah. Misalnya, mereka meminta fatwa kepada Majelis Ulama Indonesia (MUI) bahwa program deradikalisasi Islam merupakan paradigma yang salah.Sebab, dalam pandangan kelompok ini, kata 'deradikalisasi Islam' memiliki implikasi makna 'de-Islamisasi masyarakat Indonesia'. Dalam konteks ini, mereka membuat beberapa buku yang isinya adalah hubungan deradikalisasi dan dampaknya terhadap kondisi umat Islam di Indonesia. Sebut saja buku "Kritik Evaluasi dan Dekonstruksi Gerakan Deradikalisasi Akidah Muslimin Indonesia". Tak ayal, MUI pun menanggapi hal tersebut dengan meminta pemerintah menarik buku deradikalisasi tersebut. Meski hal ini diungkapkan oleh salah seorang pengurus MUI, bukan

${ }^{29}$ Masdar Hilmy, "The Politics of Retaliation: The Backlash of Radical Islamists to Deradicalization Project in Indonesia", Jurnal al Jamiah, Vol. 51, No. 2, 2013, h. 130 sikap organisasional. ${ }^{30}$ Pada bagian ini, secara fenomenologis, semestinya para pemegang otoritas Islam harus berupaya mengambil alih kekuatan sosial dan keagamaan yang ada di dalam kehidupan masyarakat Islam. Tidak boleh sekedar memberikan statement politik semata, melainkan benar-benar bisa berbaur dengan kelompok masyarakat pada lingkup dan ruang terkecil di masyarakat.

Fenomena kedua, pada persegeseran otoritas keagamaan, tampaknya terletak pada diskursus "how Muslims expressed and considered their religion". Artinya, terkait tentang wacana bagaimana sebenarnya orang-orang Islam mengekpresikan nilai-nilai keberagamaan di ruang publik. Tulisan Siti Nurul Hidayah bukan persoalan kekalahan otoritas para Ulama NU-Muhammadiyah, cendikiawan Muslim, dan para otoritarian Islam lain yang lebih memiliki kemampuan untuk memberikan pemahaman kepada umat Islam terkait Islam. Hanya saja, harus diakui, para kiai, Ulama Muhammadiyah, dan cendikiawan Muslim, acapkali mengambil jarak (efek dari kesadaran keagamaan mereka) terhadap halhal yang berbau komersial. Dalam pandangan dan kesadaran para kiai misalnya, ekspresi keislaman dan kesadaran keislaman adalah sebuah manifestasi individual, kematangan mental, dan kemampuan untuk memisahkan mana yang termasuk nafsu keduniawian dan ke-akhiratan. Para kiai ada pada level tidak merasakan kepantasan mengekspresikan keislaman secara berlebihan. Mereka ada pada kadar-kadar bagaimana masyarakat awam tinggal dalam kesederhanaan. Di pihak lain, kelompok intelegensia muslim pun demikian. Mereka selalu beranggapan ruang 'ceramah agama' (berbasis nilai-nilai keluhuran Islam) bukan bagian ajaran yang diyakini sebagai kebenaran kolektif. Mereka seakan ingin memberikan ruang pembenahan hati umat Islam pada orang-orang yang tidak sekedar alim, namun abid (ahli beribadah).

${ }^{30}$ Lihat MUI Pusat Minta Buku "Gerakan Deradikalisasi" ditarik" http://nahimunkar.com/9937/mui-pusat-minta-buku\%E2\%80\%9Cgerakan-deradikalisasi\%E2\%80\%9Dditarik, (diakses pada 23 Desember 2017) 
Fenomena ketiga, persoalan perebutan otoritas di ruang media elektronik dan sosial. Berbeda dengan dua percaturan dan kontestasi sebelumnya yang cenderung melibatkan dualitas aktor dan struktur; ulama dan organisasi keagamaan, ruang ini lebih pada intersubjektifitas seorang ulama dan netizen (masyarakat internet). Penulis, pada posisi ini, bersepaham dengan Cloete, bahwa Audience-lah yang hari ini memiliki otoritas penuh terhadap nilai-nilai keberagamaan yang dikontestasikan itu. Bukan lagi tokoh, cendikiawan Islam, ulama, ustadz, atau entitas lainnya. Sebab, masyarakat dunia maya ini akan mencari sendiri pandangan hukum, Islam, dan produk pemikiran lainnya, secara acak. Secara subjek- auidence, mereka memiliki hak untuk menseleksi mana pandangan yang pantas dan kemana mereka menyandarkan sikap dan pandangannya sendiri secara bebas dan leluasa. Malahan, tidak jarang terlihat, ketika pemegang otoritas ini sedang berada pada gazwah-firiyyah al diniyah di dunia maya, mereka memilih apatis pada kedua-duanya, lalu keluar dari perdebatan dan mengembalikan pada pengalaman-pengalaman keagamaan yang dilaluinya semasa masih kecil. Jadi, pertarungan di dunia sosial, dalam pandangan penulis, tidak dapat mengkristalisasi sikap keagamaan. Secara fenomenologis, orang yang menghadirkan sikap keagamaan dari dunia maya, akan menghadapi realitas yang ada di depannya. Mereka masih membutuhkan tensi-dialektis antara apa yang mereka baca dan pahami, dengan kondisi sosial dimana mereka hidup.

\section{Diskusi Solutif Pengembalian Otoritas Fatwa}

Persoalan-persoalan otoritas keagamaan yang sudah penulis paparkan, sebenarnya, masih akan menghiasi perdebatan dan perbincangan paham keislaman; apakah itu dari sudut pandang hukum, metodologis, antropologis, sosiologis, dan bahkan fenomenologis. Pada sisi hukum, Wael B. Hallaq sudah memberikan pandangan koherennya bagaimana semestinya persoalanpersoalan interpretasi jurisdistik harus membingkai pandangan hukum Islam; dimulai dari produk ijtihad, mazhab, bertaklid, dan melakukan kontekstualisasi hukum berdasarkan sumber- sumber yang sudah disepakati bersama. ${ }^{31}$ Dalam pandangan yang lebih sederhana, pemegang otorititas keagamaan, sebaiknya memiliki pemahaman menyeluruh bagaimana hukum Islam dilahirkan. Tidak selalu harus menggunakan pandangan individual dan reduktif, layaknya yang trend pada akhir-akhir ini. Semua orang bersepakat bahwa ada prosedur baku dalam mengeluarkan fatwa atau produk hukum Islam. Semua orang paham, jawaban hukum Islam harus berlandaskan pada cara berfikir yang runtut, mulai dari pandangan teks, sejarah, hingga konteks yang harus dibedah. Pada masa lalu, para pemegang otoritas keagamaan, secara sadar mempertontonkan itu dengan sangat hati-hati. Mereka yang modernis menulis buku dan gagasan yang dibingkai pada tradisi rasional. Sebaliknya, kelompok tradisional harus membedahnya menggunakan kitab-kitab otoritatif (mu'tabarah), didiskusikan kemudian baru difatwakan kepada masyarakat. ${ }^{32}$

Pada fase sosiologis, kontestasi 'siapa yang paling Islam' harus disadari sekedar sebagai kegairahan dalam berdiskursus. Kegairahan bagaimana sebenarnya Islam memang memiliki ragam wajah, ragam interpretasi, dan ragam internalisasi. Islam—pasca kenabian—sudah mengalami banyak metamorfosa dialektis. Para ulama dan cendikiawan Muslim menyadari bahwa mengembalikan Islam seperti era Nabi Muhammad sudah tidak mudah lagi. Mengembalikan hukum memiliki satu otoritas mutlak, pun sudah tidak bisa lagi. Maka yang terpenting adalah kesadaran akan keragaman dalam pandangan-pandangan keberagamaan. Bukan sebaliknya, kesadaran untuk kembali menyeragamkan cara pandang dan mengambil alih (pemangku) otoritas teks dan kenabian. Bahwa, ada kecenderungan kelompok masyarakat yang menganggap MUI secara kelembagaan merupakan wakil intrepretator ayat Tuhan paling sah, itu adalah sebuah kebenaran. Tapi, menegasikan bahwa ada ulama dan organisasi Islam yang berpandangan berbeda terhadap fatwa itu, hal ini juga sebuah keniscayaan. Pada

${ }^{31}$ Wael B. Hallaq, Authority, Continuity, and Change in Islamic Law, (London; Cambrige University Press, 2001), h. $\mathrm{x}$

32 Jajat Burhanuddin "Traditional Islam and Modernity;... , h. 71 
pandangan fenomenologi-historis, fenomena yang demikian sudah berjalan sekian tahun lamanya, bahkan kalau melihat apa yang ditulis Rumadi, perdebatan otoritas keagamaan sudah menjadi isu di era sahabat. ${ }^{33}$

Terakhir, penulis ingin menghadirkan kecenderungan berfikir fenomenologi Islam itu lebih membuat seseorang tenang dibandingkan harus mengikuti arus perubahan sosial dan antropologis. Akhir-akhir ini penulis mulai mengamati tokoh agama ingin mengajak umat Islam untuk memahami apa itu Islam menurut pandangan mereka, tanpa sebuah pemaksaan terhadap lainnya. Artinya, para Ulama dan tokoh Islam ini mendiskomposisi pemahaman keislamannya sesuai pada reduksi dirinya sendiri. Karya Abdurrahman Wahid "Islamku, Islam Anda, Islam Kita” adalah buku yang menarik bagaimana seorang tokoh menampilkan pemahaman dan membedakan dirinya dengan orang lain. Sedang reader diberikan keleluasaan untuk memilih. Abdurrahman Wahid tidak ingin menggunakan otoritas keulamaan yang dimiliki agar selalu diikuti oleh semua Umat Islam. ${ }^{34}$ Ada satu lagi, buku berbasis fenomenologisme (baca; struktur kesadaran yang dikontestasikan) adalah karya Quraish Shihab dengan judul "Islam yang Saya Anut”. Quraish Shihab ingin mengajak umat Islam memahami bahwa melalui keilmuan dan keilmiahan yang luaslah keislaman dirinya terbangun. ${ }^{35}$ Dua buku ini mengindikasikan bahwa keislaman semestinya menjadi nilai diterminan pada diri sendiri. Tidak harus selalu dipaksakan pada masyarakat lain. Agar, keberadaan agama tidak berimbas kontra produktif, sehingga menghasilkan karya-karya seperti milik Betrand Russell ${ }^{36}$ dan Ibnu Waraq ${ }^{37}$ yang mempertanyakan nilai agama bagi dirinya.

${ }^{33}$ Rumadi, “Islam dan Otoritas...", Jurnal Walisongo, Vol. 20, No 1, 2012, h. 33

${ }^{34}$ Abdurrahman Wahid, Islamku, Islam Anda, Islam Kita, (Jakarta; The Wahid Institute, 2005), h. ii

${ }_{35}$ M. Quraish Shihab, Islam yang Saya Anut; Dasar-Dasar Ajaran Islam, (Tanggerang Selatan; Lentera Hati, 2018), h. 30

${ }^{36}$ Betrand Rhussel, Why I am Not Christian (New York; Catalog Congress, 1927), h. 23

37 Ibnu Warraq, Why I am Not a Muslim (New York; Prometheus Books, 1995), h. 25

\section{Penutup}

Setidaknya, inilah yang ingin penulis ungkapkan untuk menilai pergeseran otoritas keberagamaan berdasarkan pada paradigma fenomenologisme agama. Penulis berkesimpulan, keragaman otoritas pasca risalah kenabian adalah sebuah keniscayaan. Keragaman otoritas juga disosialisasikan menggunakan cara-cara yang sudah berbeda dari sebelumnya ada. Demikian halnya, para audience (masyarakat yang bertanya ataupun mendengarkan jawaban dalil-dalil keberagamaan) memiliki keragaman untuk membaca otoritas keagamaan itu ditunjukkan di media elektronik ataupun sosial. Keragaman pembacaan misalnya, bagi kalangan santri, lebih berbeda dibandingkan umat Islam di dalam masyarakat urban. Oleh karena itu pula, bagi seorang pemberi fatwa, mereka memiliki pertimbangan fenomenologis kepada siapa fatwa itu disampaikan. Jadi, harus disadari pula bahwa struktur kesadaran yang ada di masyarakat menjadi ladang pertarungan hegemoni; meskipun mereka juga memiliki instrumen kebenaran terkait apa sebenarnya Islam itu. Pada akhirnya, untuk keluar dari perdebatan itu, penulis menawarkan agar otoritas keagamaan diletakkan pada wujud yang tidak memaksakan kehendak pada orang lain. Pemegang otoritas harus memiliki kesadaran akan tanggung jawabnya sebagai penerus ajaran keagamaan di Indonesia. Demikian pula, mereka harus menyadari dimana mereka harus bertarung; di media meanstream, media sosial, atau lainnya. Terakhir, penulis mengharapkan adanya keseragaman berfikir bahwa otoritas keagamaan yang melekat itu mesti disosialisasikan berdasarkan prosedur yang disepakati bersama, tidak sekedar karena ketokohan seseorang semata.

\section{Pustaka Acuan}

A, SJ Sudiarja, Pengantar, dalam Mariasusai Dhavamony, Fenomenologi Agama, Yogyakarta: Kanisius, 1999.

Allen, Douglas, "Phenomenology of religion" dalam J. R Hinnels, Rutledge Companion of Religious Study, New York; Routledge, 2005.

Artikel terkait media dan otoritas pemikiran Islam pada https://www.hidayatullah.com/ 
artikel/ghazwul-fikr/read/2017/02/16/111930/ sihir-media-dan-kampanye-anti-otoritasagama.html, diakses pada tanggal 10 Januari 2018.

Azra, Azyumardi, Kees Van Dijk, dan Nico J.G Kaptein, Varieties of Religious Authority; Changes and Challenges in $20^{\text {th }}$ Century Indonesian Islam, Singapore, ISAS Publishing, 2010.

Burhanuddin, Jajat "Traditional Islam and Modernity; Some note Changing of the Ulama in early $20^{\text {th }}$ Century Indonesia" dalam Azyumardi Azra, Kees Van Dijk, dan Nico J.G Kaptein, Varieties of religious Authority; Changes and Challenges in $20^{\text {th }}$ Century Indonesian Islam, Singapore, ISAS Publishing, 2010.

, "The Fragmentation of Religious Authority; Islamic Printed Media in Early 20 ${ }^{\text {th }}$ Century Indonesia", Jurnal Studia-Islamika, Vol. 11, No. 1, 2004.

Chados, R..., 'Reflectons on the Impact of "The Digital Revoluton" on Art and Religion', Journal of Associaton for Religion and Intellectual life", Vol. 62, No. 2, 2012.

Cloete, Anita L., “Mediated Religion: Implicatons for Religious Authority" AOSIS. Tahun 2016.

Cox, James L., Exspressing the Sacred: An Introduction to the Phenomenology of Religion, Harare: University of Zimbabwe, 1992.

Dhavamony, Mariasusai, Fenomenologi Agama, terj. Tim Kanisius, Yogyakarta: Kanisius, 1999.

Ekeke, Rev. Emeka C. \& Chike Ekeopara, "Phenomenological Approach to The Study of Religion A Historical Perspective," European Journal of Scientific Research, Vol. 44, No. 2, 2010.

Fadilah, Silvia, “Korelasi Tingkat Adiksi Masyarakat terhadap Internet dalam Pemahaman Keagamaan" dalam JurnalAl Afkar, No 4 Vol 1 Tahun 2014.

Hallaq, Wael B., Authority,Continuity, and Change in Islamic Law, London; Cambrige University Press, 2001.

Hilmy, Masdar, The Politics of Retaliation: The Backlash of Radical Islamists to Deradicalization Project in Indonesia, Jurnal al Jamiah, Vol. 51 No. 2, 2013.

Jinan, Mutohharun, “New Media dan Pergeseran Otoritas Keagamaan Islam di Indonesia" Jurnal Lektur Keagamaan, Vol. 10, No. 1, 2012: 181-208. Lihat tulisan serupa, Mutohharun Jinan “Intervensi New Media dan Impersonalisasi Otoritas Keagamaan di Indonesia", Jurnal Komunikasi Islam Vol. 03, No. 02, 2013.

Kramer \& S. Schidtke (eds), Speaking for Islam: Religious authorities in Muslim Societies, Leiden: Brill Academic Publishers, 2006.

Leeuw. Geradus Van der, Fenomenologia Della Religion, Torino: Bollati Boringhieri, 1992.

Liputan detik Pada tahun 2016 terkait MUI Larang Penggunaan Atribut natal bagi umat Islam" https://news.detik.com/berita/d-3373614/ fatwa-haram-penggunaan-atribut-nonmuslimmui-itu-hanya-untuk-umat-islam, diakses pada 10 Januari 2017.

MUI Pusat Minta Buku "Gerakan Deradikalisasi" ditarik” http://nahimunkar.com/9937/muipusat-minta-buku-\%E2\%80\%9Cgerakan-derad ikalisasi\%E2\%80\%9Dditarik/, diakses pada 23 Desember 2017.

Noor, Haula, "Dinamikan Otoritas Keagamaan di Indonesia" Jurnal Indo-Islamika Vol. 1 No. 2, 2012.

Opini Koran Sindo: Najib Burhani Aksi Bela Islam dan Fragmentasi Otoritas keagamaan: https:// nasional.sindonews.com/read/1168539/18/ aksi-bela-islam-dan-fragmentasi-otoritaskeagamaan-1483668174, diakses pada tanggal 10 Januari 2018.

Opini Siti Nurul Hidayah "Tele Dai dan Persolan Otoritas Keagamaan” https://news.detik. com/kolom/d-3770783/tele-dai-dan-persoalanotoritas-keagamaan, diakses pada tanggal 10 Januari 2018.

Rhussel, Betrand, Why I am Not Christian, New York: Catalog Congress, 1927.

Rumadi “Islam dan Otoritas Keagamaan”, Jurnal Walisongo, Vol. 20, No. 1, 2012.

Shihab, M. Quraish, Islam yang Saya Anut; DasarDasar Ajaran Islam, Tanggerang Selatan; Lentera Hati, 2018. 
MADANIA Vol. 22, No. 1, Juni 2018

Wahid, Abdurrahman, Islamku, Islam Anda, Islam Kita, Jakarta: The Wahid Institute, 2005.
Warraq, Ibnu, Why I am Not a Muslim, New York: Prometheus Books, 1995. 